\title{
Variations in sound-producing mechanism in the pearlfish Carapini (Carapidae)
}

\author{
E. Parmentier ${ }^{1,2}$, J.-P. Lagardère ${ }^{3}$, Y. Chancerelle ${ }^{2}$, D. Dufrane ${ }^{1}$ \& I. Eeckhaut ${ }^{4}$ \\ 1 Laboratoire de Morphologie Fonctionnelle et Evolutive, Institut de Chimie, Université de Liège, Liège, Belgium \\ 2 Centre de Recherche Insulaire et Observatoire de I'Environnement, CRIOBE/EPHE, Moorea, French Polynesia \\ 3 CREMA-L'Houmeau (CNRS-Ifremer), L'Houmeau, France \\ 4 Marine Biology, University of Mons-Hainaut, Mons, Belgium
}

\author{
Keywords \\ Carapus; Encheliophis; sonic; swimbladder.

\section{Correspondence} \\ Eric Parmentier, Laboratoire de \\ Morphologie Fonctionnelle et Evolutive, \\ Institut de Chimie, Bât. B6C, Université de \\ Liège, B-4000 Liège, Belgium. Tel: + 0032 \\ (0)4 36640 24; Fax: + 0032 (0)4 3665024 \\ Email: E.Parmentier@ulg.ac.be \\ Editor: Jean-Nicolas Volff
}

Received 20 March 2008; revised 28 May 2008; accepted 10 June 2008

doi:10.1111/j.1469-7998.2008.00486.x

\begin{abstract}
Sound production in Carapus boraborensis results from the action of different sonic muscles terminating in complex tendons, which have hooks that fit over a tubercle on the swimbladder wall. The primary sonic muscles (PSM) draw progressively the forepart of the swimbladder until the hook releases the tubercle. This allows the swimbladder to snap back to its resting position, which initiates the onset of the sound. In the present study, the morphology of the C. boraborensis sound-producing apparatus and the resulting sounds were compared with Encheliophis gracilis and Carapus homei. The main difference concerns the direct insertion of the PSM on the swimbladder in C. homei and E. gracilis and, concurrent sonic characteristics. These morphological features also allow both fish to produce an additional kind of sound with more compact pulses, each being clearly composed of two parts and each having a different frequency. The soundproducing system could be compared with a guitarist who makes a sound in releasing a guitar string and modulates it by moving his/her finger along the string. However, E. gracilis possess more filtered sounds than C. boraborensis and $C$. homei, probably because of the unusual shape of its swimbladder. This study highlights the diversity and plasticity of sonic mechanisms and their implication in the development of sonic repertoire in evolving species.
\end{abstract}

\section{Introduction}

Certain Carapidae, known as pearlfish, are small, eel-like fishes that live inside invertebrate hosts (Trott, 1970). Species of the Carapini tribe (Carapus and Encheliophis) are mainly found in the respiratory trees or inside the body cavity of different holothurian species (Arnold, 1956; Smith, 1964; Shen \& Yeh, 1987). Carapus species are commensals and use their hosts as shelters, while Encheliophis species are parasitic and eat the host's gonads (Parmentier \& Vandewalle, 2003; Parmentier \& Das, 2004).

Sounds have been recorded in different Carapus species (Parmentier, Vandewalle \& Lagardère, 2003; Lagardère, Millot \& Parmentier, 2005; Parmentier et al., 2006a,b): Carapus boraborensis, Carapus homei, Carapus mourlani and Carapus acus. All recorded sounds appear to be species specific. Carapini display specializations of the anterior vertebrae, swimbladder and associated muscles (Emery, 1880; Courtenay \& McKittrick, 1970; Markle \& Olney, 1990; Parmentier et al., 2000). These structures appear to be a sound-producing device. In $C$. boraborensis, it was recently shown that the primary sonic muscles (PSM) terminate in a complex tendon, the 'tendon-hook' system (THS), which includes a 'hook' that fits over a tubercle on the dorso-anterior wall of the swimbladder. The muscles contract slowly, pulling the anterior bladder. The sound is produced when the swimbladder is released, snapping back to its resting position, and this sets the swimbladder plate into motion. Energy from plate motion would then be transferred through the fenestra and would excite the bladder to produce sound. This tension-release mechanism seems unique in animal sound generation, and it is also the first example of sound production with a slow sonic muscle (Parmentier et al., 2006a). The THS has been found in C. boraborensis (Parmentier et al., 2006a), C. acus and C. mourlani (pers. obs.). Another important feature of this Carapus sound-producing system lies in the unique myofibrillar helical organization providing the muscle with spring-like mechanical properties (Parmentier et al., 2003). The uncoiling of the helix during relaxation would help in the lengthening of the muscle. Additionally, a second pair of sonic muscles, the secondary sonic muscles (SSM), could also influence sound production (Courtenay \& McKittrick, 1970). These muscles originate on the posterior part of the skull and insert on the two first epineural ribs, which are connected to the anterior part of the swimbladder by ligaments. In contrast to the PSM, these muscles have never been closely examined. 
It is widely assumed that temporal parameters (sound length, period, etc.) are the main features in acoustic fish communication (Winn, 1964; Myrberg, Spanier \& Ha, 1978; Hawkins \& Myrberg, 1983; Hawkins, 1993; Mann \& Lobel, 1998). On the other hand, spectral frequencies, and perhaps sound intensity, might also have a biological importance for inter- and intra-specific recognition in fish (Ladich, Brittinger \& Kratochvil, 1992). This spectral and temporal variability is based at minimum on morphological characteristics. The best example in fish sound variation due to morphology is linked to swimbladder size: the pulse duration increases and the dominant frequency decreases in larger fishes (Ladich et al., 1992; Lobel \& Mann, 1995; Connaughton, Taylor \& Fine, 2000). Parmentier et al. (2006a) demonstrated in $C$. boraborensis that peak frequency of manually generated sounds decreased over an octave from almost $500 \mathrm{~Hz}$ in a female with a $25.3-\mathrm{mm}$-long bladder to about $170 \mathrm{~Hz}$ in a female with a $38 \mathrm{~mm}$ bladder.

Other morphological studies are sparse. Carapus mourla$n i$ and $C$. acus possess a shorter pulse duration, a higher peak frequency and a less sharp tuning than is the case in C. boraborensis and C. homei (Parmentier et al., 2006b). It has been suggested that these differences could be due to the presence of a central constriction of the swimbladder in the former group, which is not present in $C$. homei and C. boraborensis. Moreover, fishes of the $C$. mourlani group can only have conspecific encounters in their host, whereas they can be heterospecific for C. homei and C. boraborensis (Markle \& Olney, 1990; Parmentier et al., 2000). The latter difference could explain why the pulses are shorter and less repetitive in $C$. acus and $C$. mourlani. As an individual entering a sea cucumber, which is already inhabited by the same or a different species, can lead to eviction or death (Lagardère et al., 2005; Parmentier \& Vandewalle, 2005), it would be adaptive to produce repetitive calls. This constraint could be less important in $C$. acus and $C$. mourlani because they have no chance of encountering another fish species in the host. On the other hand, C. boraborensis, C. homei and Encheliophis gracilis can be found in the same host species, at the same depth and in similar waters (Parmentier \& Vandewalle, 2005).

The parasitic species E. gracilis possess a wide geographical distribution in the Indo-Pacific, from East Africa to Hawaii. This widespread distribution is likely due to the dispersive ability of the coral-reef larvae (Leis, 1991, 2002). Larval dispersal is dependent on the duration of larval life (between hatching and settlement on the reef), current strength and direction, swimming behaviour and the mortality rates of the larvae (Munro \& Williams, 1985). In E. gracilis, the pelagic larval period is particularly long: more than 70 days (Parmentier, Lagardère \& Vandewalle, 2002; Colleye et al., 2007). Encheliophis gracilis has been reported to produce two kinds of sounds in French Polynesia: single beats or drum rolls (Parmentier et al., 2003). However, the description of the sounds was only given for the single beats, and was not accurate enough for the drum rolls.

The aim of this study is to understand more deeply the links in Carapini between morphology and the resulting ability to make sounds. The mechanism of sound production in the parasitic E. gracilis is compared with that of commensal species (C. homei and $C$. boraborensis) in order to discover how morphological differences can influence sound parameters in closely related species.

The aim of this study is to understand more deeply the links in Carapini between morphology and the resulting ability to make sounds. The sound and the mechanism of sound production were described in C. boraborensis; only the sounds were presented in $C$. homei and data are lacking for the sound and the mechanism in the parasitic E. gracilis. This study completes the published data in order to show how morphological differences can influence sound parameters in closely related species.

\section{Material and methods}

Four specimens of the sea cucumber Bohadshia argus were collected by scuba diving in the lagoon in front of the coast of Tulear (Mozambique Channel, west coast of Madagascar, $\left.23^{\circ} 220 \mathrm{~S} ; 46^{\circ} 390 \mathrm{E}\right)$ in November 2005 . The sea cucumbers were placed in a tank $(3.5 \times 0.7 \times 0.2 \mathrm{~m})$ filled with seawater $\left(26^{\circ} \mathrm{C}\right)$. Three holothurians were cut longitudinally and two E. gracilis (TL: $18.5-22 \mathrm{~cm}$ ) were found inside each specimen. The sex was impossible to determine using external features. These fish were stored in a glass tank $\left(1 \times 0.5 \times 0.6 \mathrm{~m}, 26^{\circ} \mathrm{C}\right)$ in natural day-night cycle and were not fed for a period of $24 \mathrm{~h}$ before the experiments. Two specimens of E. gracilis (TL: 20-24cm), 11 specimens of C. homei (TL: $8-15 \mathrm{~cm}$ ) and 11 specimens of C. boraborensis (TL: $8-23 \mathrm{~cm}$ ) were also collected by scuba diving in front of Opunohu Bay, Moorea, French Polynesia. These fishes, used for morphology examination, were found in specimens of the sea cucumbers Thelenotas ananas and B. argus, respectively.

The sounds were recorded under the same conditions as those used by Parmentier et al. (2003, 2006b) for C. homei and $C$. boraborensis. Sounds were recorded in a glass aquarium $(1 \times 0.5 \times 0.6 \mathrm{~m})$ containing the sea cucumber, above which a hydrophone was placed at a distance of $<20 \mathrm{~cm}$. For each experiment, individuals were introduced one after the other into the aquarium in order to allow enough time for each one to enter the sea cucumber host. Six fish were used for the experiments. However, the sounds were made once the fish was inside the sea cucumber; it was thus impossible to identify the emitting fish. Sounds were recorded with an Orca hydrophone (sensitivity: $-186 \mathrm{~dB}$

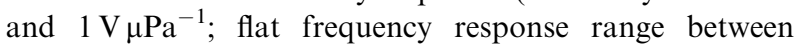
$10 \mathrm{~Hz}$ and $23.8 \mathrm{kHz}$ ) connected via an Orca-produced amplifier (ORCA Instrumentation, Brest, France) to a Sony TCD-D8 digital audio tape-recorder (Liège, Belgium) (recording bandwidth: $20-22000 \mathrm{~Hz} \pm 1.0 \mathrm{~dB}$ ). Sounds were digitized at $44.1 \mathrm{kHz}$ (16 bit resolution) and analysed with AvisSoft-SAS Lab Pro 4.33 software (Avisoft Bioacoustics, Berlin, Germany). The resonant frequency of the tank was $2.1 \mathrm{kHz}$ and the corresponding low-pass filters were applied (Akamatsu et al., 2002). Temporal features were measured from the oscillograms, and frequency parameters were obtained from power spectra (filter bandwidth $300 \mathrm{~Hz}$, 


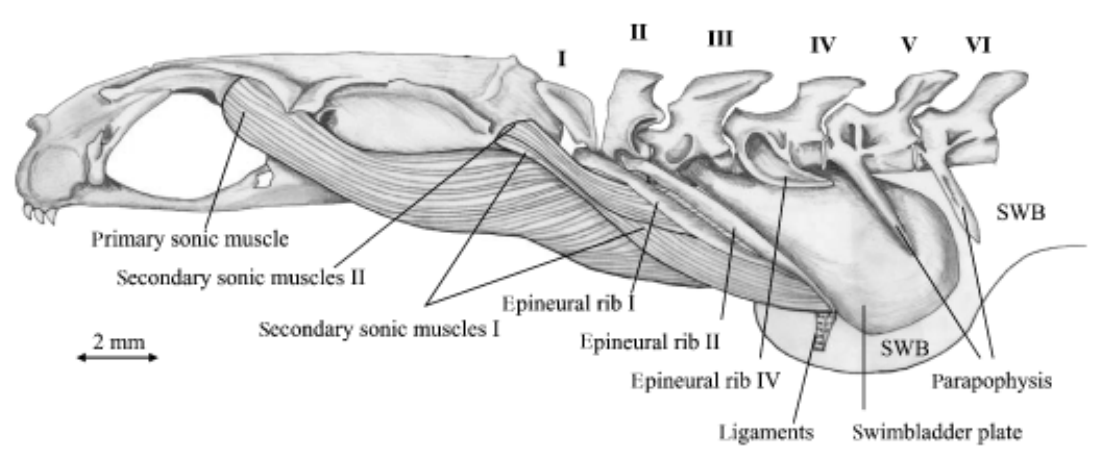

Figure 1 Left lateral view of the anterior part of the sound-producing system in Encheliophis gracilis. SWB, swimbladder.

FFT size 256 points, time overlap $96.87 \%$ overlap and a Hamming window). The following sound parameters were measured: (1) sound duration [time elapsed from the start of the first pulse to the end of the last pulse (ms)]; (2) number of pulses in a sound; (3) pulse period [average peak-to-peak interval between consecutive pulse units in the entire sound (ms)]; (4) pulse duration (time elapsed from the start and the end of the pulse); (5) the pulse interval (time elapsed from the end of the pulse and the start of the next pulse).

Six E. gracilis specimens were deeply anaesthetized with the anaesthetic MS 222 (Sigma-Aldrich, St. Louis, Missouri, USA). Two were fixed in Bouin's solution for the production of serial histological sections. The general morphology of muscles was observed on 6-7 $\mu \mathrm{m}$ sections stained using Masson's trichrome. Small samples $\left(1 \mathrm{~cm}^{3}\right)$ of the PSM, SSM and epaxial muscle were taken from two specimens and were fixed in glutaraldehyde $2.5 \%$ for electronic microscopy (TEM). The cellular ultrastructure was examined on ultrathin sections $(60-80 \mathrm{~nm})$ stained with uranyl acetate and lead citrate. The sections were viewed with a JEOL JEM 100SX electron microscope (Jeol Ltd, Tokyo, Japan). Two fishes were placed in $75 \%$ alcohol. They were dissected and examined with a Wild M10 (Leica Camera) binocular microscope (Leica, Wetzlar, Germany) equipped with a camera lucida. Morphological observations related to $C$. homei concerned the dissection of preserved specimens. The morphology of the sonic apparatus was compared with the data obtained in specimens of $C$. boraborensis (Parmentier et al., 2002, 2003, 2006a).

This study led to results that needed deeper investigations of published data on the carapid species $C$. homei and C. boraborensis (Parmentier et al., 2003, 2006a; Lagardère et al., 2005). Sounds emitted by these fishes in the same kind of experiment were examined deeply to provide more precise comparisons with E. gracilis.

\section{Results}

\section{Morphology}

Different parts of the Carapini sound-producing system have already been described in different studies (Parmentier et al., 2003, 2006a). Some information is, however, given here for the clarity of the text. The first two vertebrae display

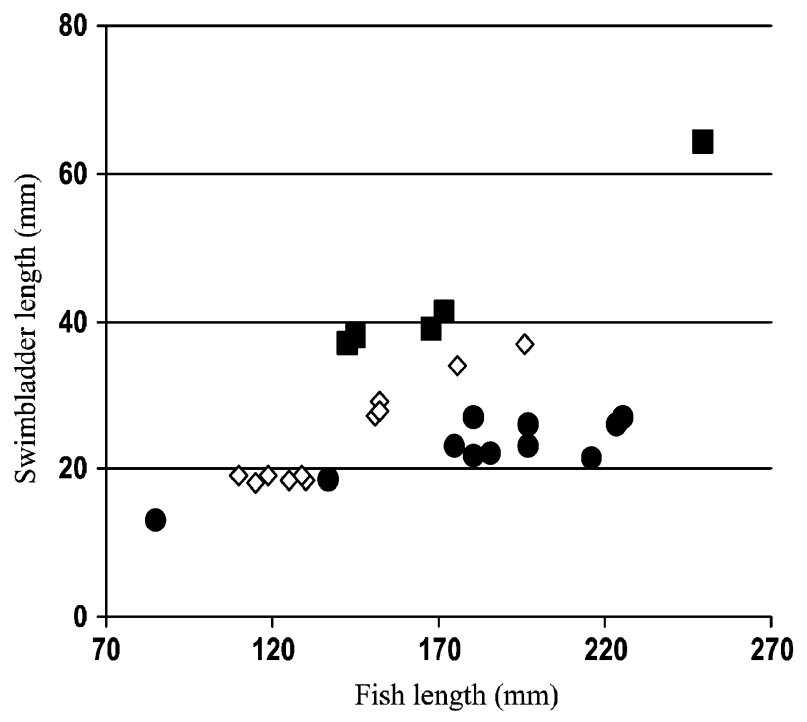

Figure 2 Relationship between the fish and the swimbladder length in Encheliophis gracilis ( $\mathbf{\square}, r=0.98)$, Carapus homei $(\diamond, r=0.96)$ and Carapus boraborensis $(\bullet, r=0.84)$.

epineural ribs, which are movable in all directions and are attached to the swimbladder by a ligament inserting on their distal tip. The ventral $(\alpha)$ SSM is inserted on the epiotic and on the distal portion of the first epineural rib. The dorsal SSM $(\beta)$ has its anterior part attached to the epiotic and joins the ventral part of the second epineural rib. The third vertebra bears a broad, ossified swimbladder plate, which attaches to the swimbladder and is fixed to the fourth epineural rib. In E. gracilis, the swimbladder plate reaches the sixth vertebra instead of the fifth vertebra in $C$. boraborensis and in C. homei (Fig. 1).

The almost cylindrical swimbladder occupies $90 \%$ of the general cavity in all three species. However, its size is $24.8 \pm 1.3 \%(n=5)$ of the total length in E. gracilis, $17 \pm 2 \%(n=11)$ in $C$. homei and $12.6 \pm 1.4 \%(n=6)$ in C. boraborensis. This results in the swimbladder extending beyond the $23 \mathrm{rd}-26 \mathrm{th}, 16 \mathrm{th}-17 \mathrm{th}$ and 11 th-12th vertebrae, respectively. The swimbladder size appears to be related to the fish size, the relationship being, however, weaker in C. boraborensis (Fig. 2). The swimbladder may be divided into three zones (Fig. 3). The PSM insert on the anterior 
(a)

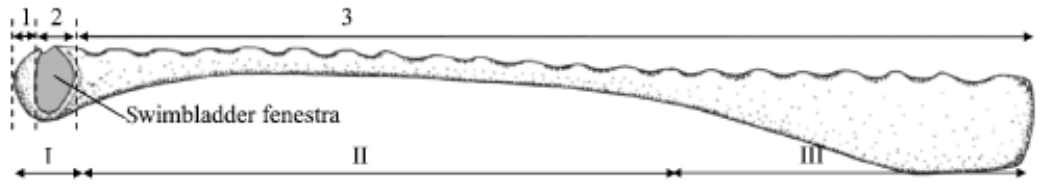

(b)

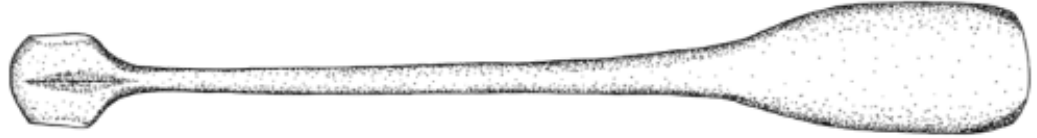

(c)

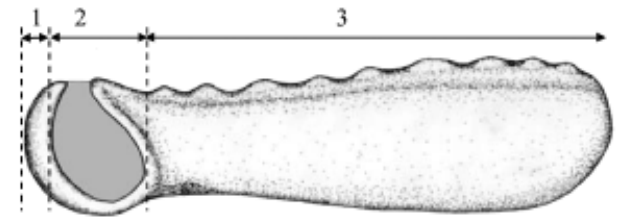

(d)

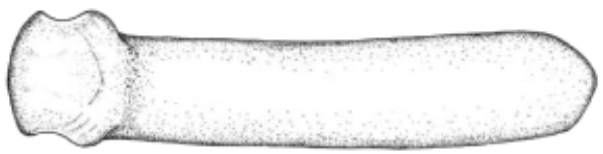

(e)

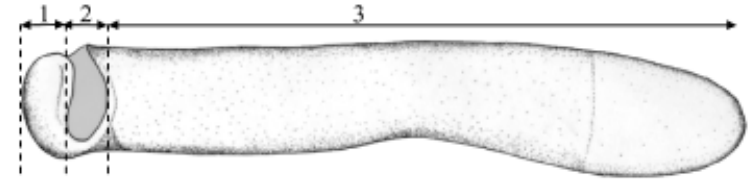

(f)

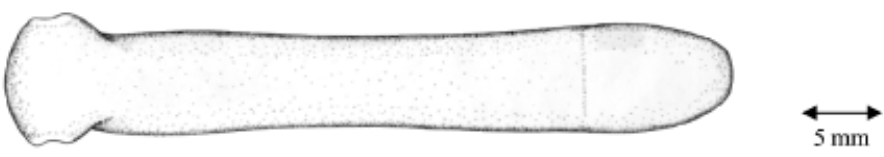

Figure 3 Left lateral $(a, c, e)$ and ventral $(b, d, f)$ views of the swimbladder in Encheliophis gracilis (a, b), Carapus boraborensis (c, d) and Carapus homei $(\mathrm{e}, \mathrm{f})$. Arabic numbers refer to the functional parts of the sound-producing system. In E. gracilis, in comparison with the Helmolthz resonator, I, external air volume; II, neck; III, chamber.

region; the wall of the second region, the "swimbladder fenestra', is situated just under the swimbladder plate and is thinner; the posterior region is long and narrow. The shape of the swimbladder is quite regular along its entire length in $C$. boraborensis and in C. homei. In E. gracilis, the anterior part of the third region is at first narrow and is then posteriorly enlarged, the caudal part being twofolds larger (Fig. 3).

The primary sound-producing muscles (PSM) are attached to the orbital roof, on the inner face of the frontal, and to the antero-dorsal portion of the swimbladder (Fig. 1). Important differences are found between species. In $C$. boraborensis, the sonic muscle terminates in a complex tendon, which includes a 'hook' that fits over a tubercle on the dorso-anterior wall of the swimbladder (Parmentier et al., 2006a,b). In C. homei and E. gracilis, the anterior part of the swimbladder does not possess small tubercles, and the PSM tendon is very short and deprived of a hook (Fig. 4). In E. gracilis PSM, the fine morphology of the sonic fibres and myofibrils is identical to that of C. boraborensis: central ones are straight, whereas peripheral ones become increasingly twisted giving to the whole a helicoidal organization
(Fig. 5a, see also Parmentier et al., 2003). In the PSM, the tubule system/sarcoplasmic reticulum ( $\mathrm{T}$ system/SR) are found at the $\mathrm{Z}$ line level and at the $\mathrm{A} / \mathrm{I}$ junctions. The mitochondria are numerous and are concentrated in packs under the sarcolem, around the myofibrils.

The organization of the myofibrils and the cellular content of the SSM correspond to the epaxial musculature. Myofibrils are parallel and occur in a straight line (Fig. 5b). The T system/SR (one T tubule + two terminal system of the sarcoplasmic reticulum) only surrounds the sarcomere at the $\mathrm{Z}$ line level. The mitochondria are sparser and are distributed in the muscles, between the myofibrils.

In E. gracilis, the PSM fibre diameter is significantly $(P<0.001)$ thinner than the SSM fibre and the white epaxial fibres (Fig. 6). There is no significant difference between the epaxial and SSM diameter (Student's $t$-test, $P=0.632$ ). The PSM myofibril diameter $(0.55 \pm 0.09 \mu \mathrm{m}, n=47)$ is significantly $\left(F_{2,101}=96, P<0.05\right)$ thinner than the SSM myofibrils $(1.08 \pm 0.21 \mu \mathrm{m}, n=25)$ and the white epaxial myofibrils $(1.02 \pm 0.25 \mu \mathrm{m}, n=30)$. There is no significant difference between the epaxial and SSM diameter (Student's $t$-test, $P=0.632$, Fig. 6). 

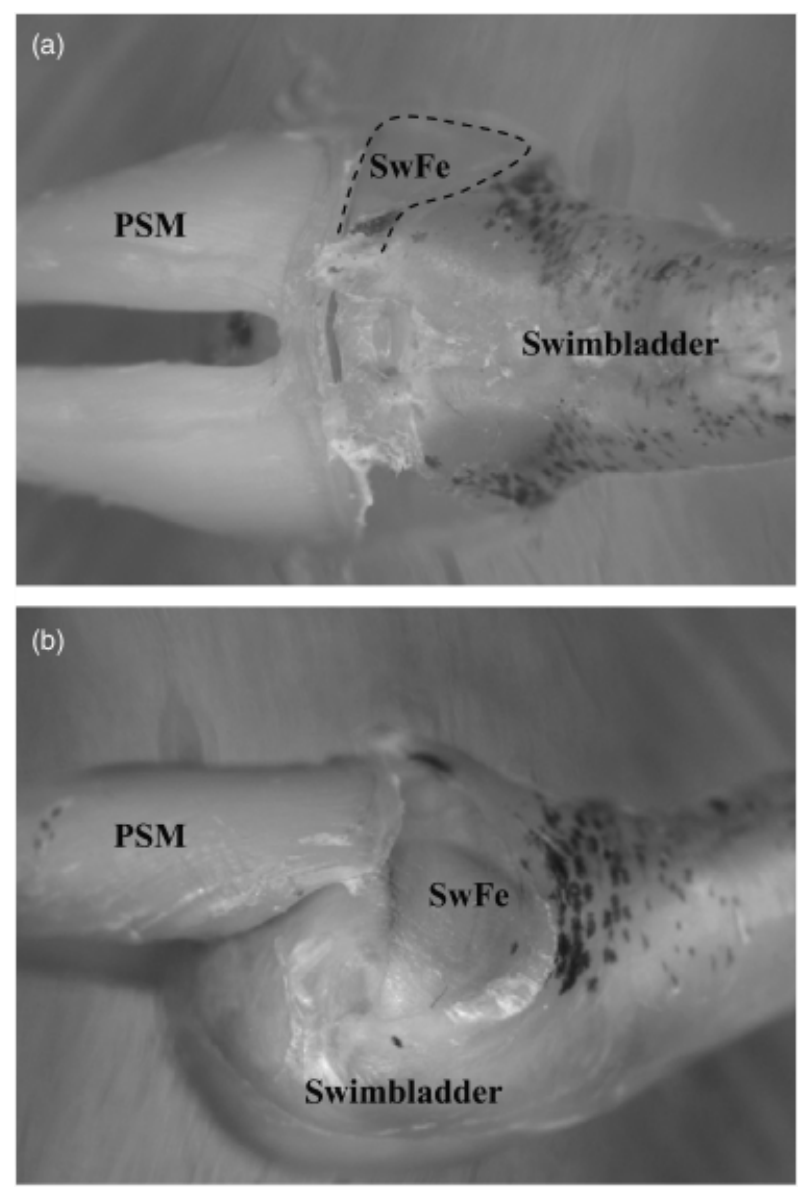

Figure 4 Insertion of the primary sonic muscle (PSM) on the swimbladder in Encheliophis gracilis. (a) dorsal view, (b) lateral view. SwFe, swimbladder fenestra.

\section{Sounds}

In each trial, sounds were only recorded when one individual entered the sea cucumber that was already occupied. So, it is impossible to observe the interactions between fishes. Encheliophis gracilis drum rolls consisted of a train of five to six pulses, each pulse lasting $(X \pm \mathrm{SE})$ $23.69 \pm 0.35 \mathrm{~ms}(n=59)$. The average of the pulse period and pulse interval was $39.89 \pm 0.79 \mathrm{~ms} \quad(n=58)$ and $16.15 \pm 0.70 \mathrm{~ms}(n=59)$, respectively. The frequency of these sounds ranged between 40 and $600 \mathrm{~Hz}$ with an average peak frequency of $157 \pm 2 \mathrm{~Hz}(n=58)$. The oscillogram shows that each pulse can be divided into two parts (Fig. 7a and $b$ ). The beginning of the sound generally has three to four cycles, and is followed by a shorter sequence in which a higher number of cycles is found. As a result, the spectrogram (Fig. 7c) shows that this second part possesses a higher frequency than the first part: \pm 3800 versus $\pm 200 \mathrm{~Hz}$. However, the sound pressure is always more pronounced in the first part of the sound, giving to the whole pulse its main energy. According to Akamatsu et al. (2002), true characteristics of sounds are hard to assess in small tanks due to their
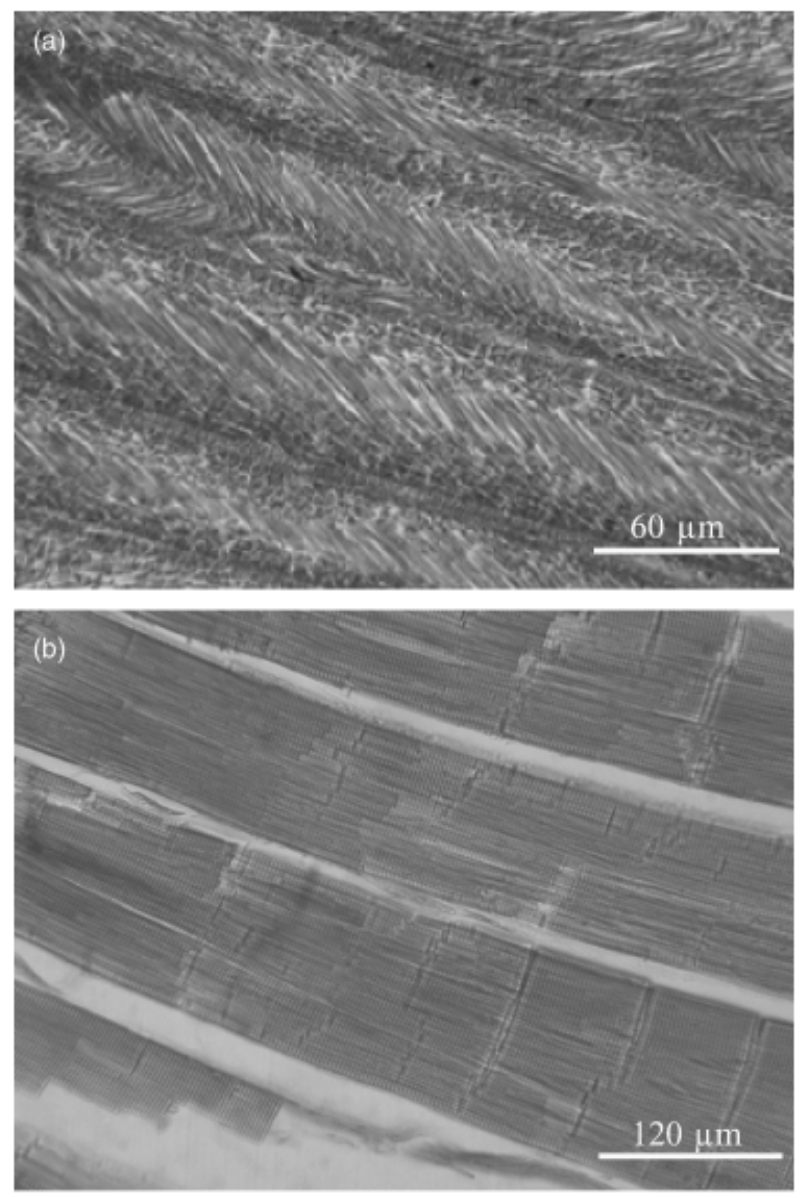

Figure 5 Longitudinal sections in the primary (a) and secondary (b) sonic muscles in Encheliophis gracilis.

physical constraints. If the resonant frequency is close to the frequency of the sounds produced by the fish, the original spectrum can be distorted. Pulsed sounds as in E. gracilis exhibit a broadband spectrum, enhancing the probability of a fish frequency component being close to the minimum resonant frequency of the tank. In this case, the resonant component of $3800 \mathrm{~Hz}$ could be overemphasized (Akamatsu et al., 2002). In the present study, the resonant frequency of the tank was $2.1 \mathrm{kHz}$ and the corresponding low-pass filters were applied (Fig. 7b): the second part of the sound still has had higher frequencies than the first part.

\section{Discussion}

The sound-producing mechanism has only been closely examined in two Carapus species: C. acus and C. boraborensis (Parmentier et al., 2003, 2006a,b). In these species, slowly pulling the sonic muscles with forceps was shown to be sufficient to generate sound pulses. The sound was produced when the tendinous hook of the PSM released the tubercle of the swimbladder, and the latter snapped back to its resting position. Apparently guided by attached connective tissue, the hook was shown to return to its locked 

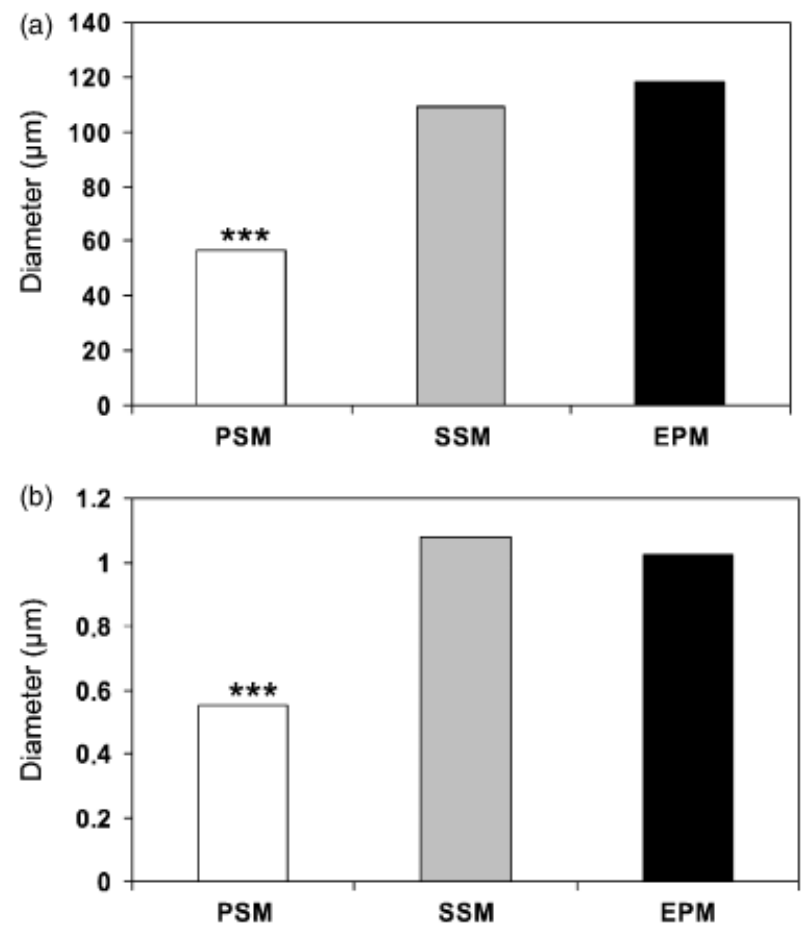

Figure 6 Fibre (a) and myofibril (b) diameters of the primary sonic muscle (PSM), secondary sonic muscle (SSM) and epaxial muscle (EPM) in Encheliophis gracilis. ${ }^{* * *} P<0.001$.

position on the tubercle during muscle relaxation (Parmentier et al., 2006a,b).

As in Carapus, the sonic fibres and myofibrils of E. gracilis exhibit the following characteristics: they have an unusual helicoidal organization, are thinner than white epaxial fibres, have numerous mitochondria in the muscle cell periphery and have $\mathrm{T}$ tubules at the A-I junctions. They also possess a swimbladder plate and a swimbladder fenestra. All these features highlight the fact that these sonic muscles are also highly specialized, and that they could work as in Carapus species (Parmentier et al., 2003, 2006a,b). However, the fine sonic mechanism appears to be different in E. gracilis and, more surprisingly, in C. homei because they do not have the THS. In these fish, muscle contraction pulls the anterior part of the swimbladder forward, stretching the swimbladder fenestra. During relaxation of the muscle, spring-like mechanical properties due to the muscle helical organization (Parmentier et al., 2003) should allow the swimbladder fenestra to snap back rapidly, originating sound. We assume that this flapping of the swimbladder fenestra corresponds to the first cycles at the onset of the pulse. The same kind of onset has, furthermore, also been found in C. boraborensis and in C. homei (Parmentier et al., 2003, 2006a). The second part of the sound is however different between $C$. boraborensis on the one hand, and $C$. homei and E. gracilis on the other hand. In C. boraborensis, the onset is followed by cycles exhibiting a slow exponential decay (Fig. 8). The second part of the sound presents cycles with a shorter period (Figs 7 and 8) in
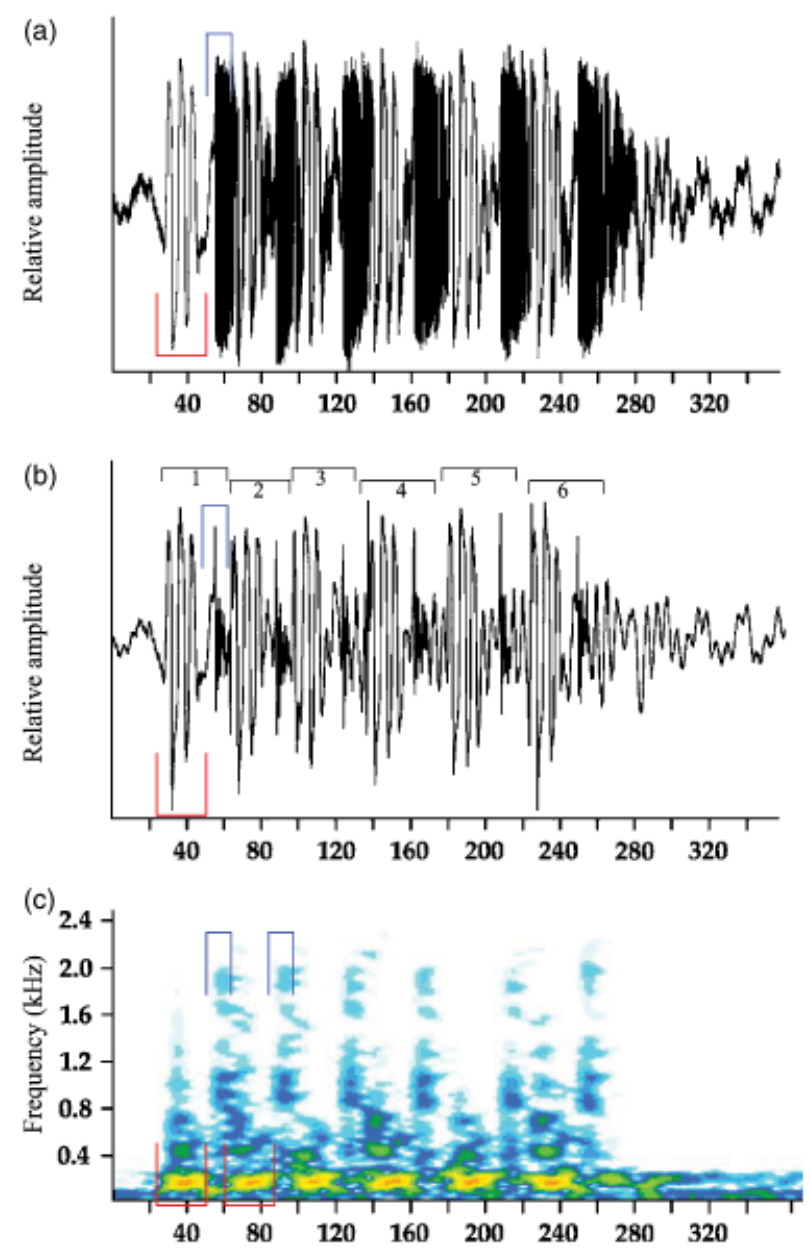

Figure 7 (a) Oscillograms of the sounds produced by Encheliophis gracilis. (b) Oscillogram of the same sound on which a low-pass filter of $3 \mathrm{kHz}$ was applied. (c) Spectrogram of the same sound. Red lines delimit the first part of the sound; blue lines delimit the second part of the sound. Spectral analysis information: sampling frequency $44100 \mathrm{~Hz}$; Windows: Hamming; bandwith: $2.18 \mathrm{~Hz}$.

C. homei and E. gracilis, giving to the call a metallic aspect. Both species have in common the absence of THS and have, consequently, direct insertion of their PSM into the swimbladder. The more high-pitched part of the sound could be linked to this common morphological trait. The direct insertion of the sonic muscle implies that the forepart of the swimbladder does not possess the ability to vibrate freely because direct muscular insertions can provoke a greater tension in the bladder walls, giving the higher-pitched sound.

The mechanism can be summarized as follows. The contraction of the sonic muscles extends the swimbladder fenestra; the relaxation of the muscle (and the elasticity of the swimbladder) causes the snapping back and the generation of the first part of the sound (lower frequency); the next contraction of the sonic muscle (or the return to its resting position after its elongation) provokes a new extension of the bladder and the second part of the sound with the higher 

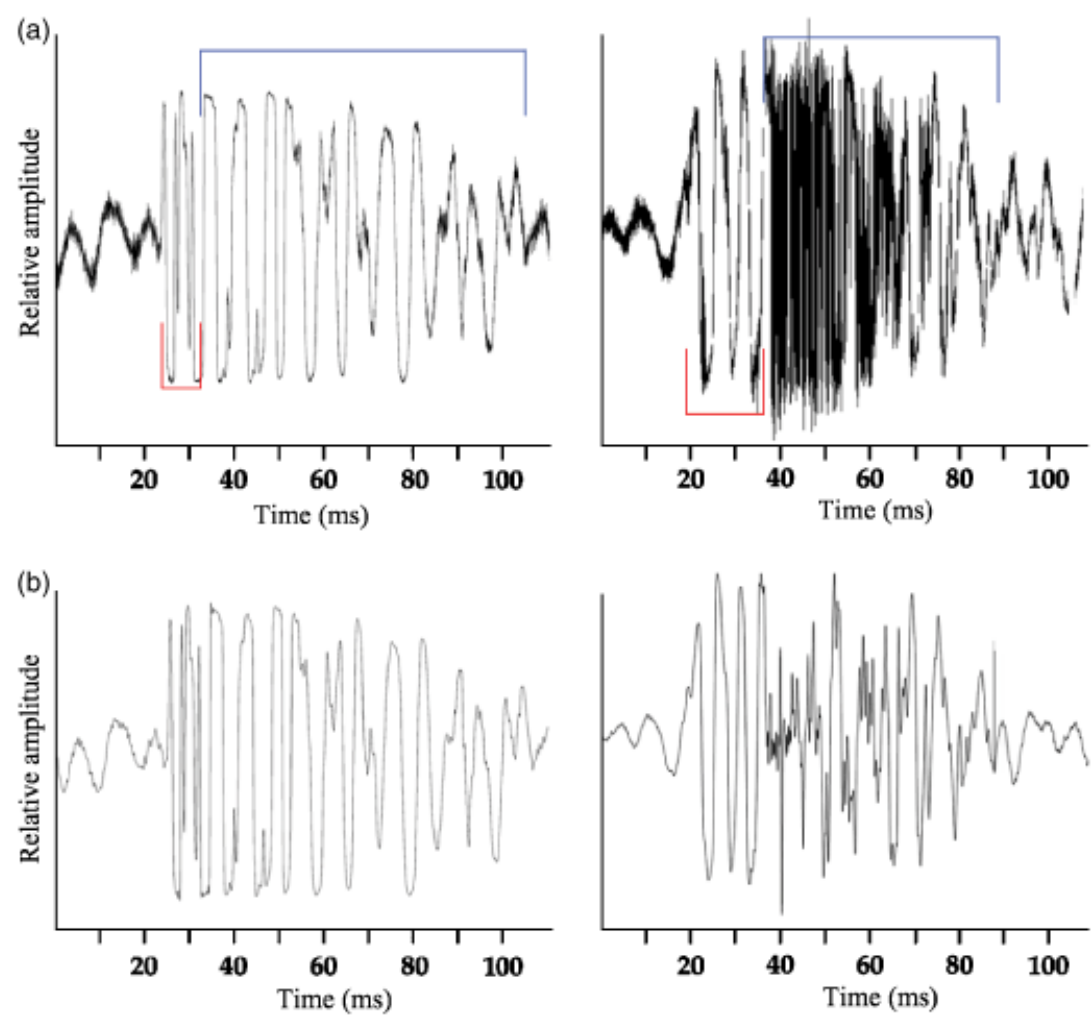

Figure 8 Oscillograms of the sounds produced by Carapus boraborensis (a) and Carapus homei (b). Right column: oscillogram of the same sound on which a low-pass filter of $3 \mathrm{kHz}$ was applied. Red lines delimit the first part of the sound; blue lines delimit the second part of the sound.

frequency. The system could be compared with a guitarist who makes a sound in releasing a guitar string (first part of the sound) and modulates it in moving his/her finger along the string (second part of the sound).

The interpulses have been shown to last $76 \mathrm{~ms}$ in C. boraborensis (Lagardère et al., 2005) versus $27 \mathrm{~ms}$ in E. gracilis, while the pulse has been shown to last on average $83 \mathrm{~ms}$ in $C$. boraborensis (Lagardère et al., 2005) versus $30-36 \mathrm{~ms}$ in E. gracilis. On the other hand, the interpulses and pulses have been shown to be shorter in C. boraborensis than in C. homei (Lagardère et al., 2005), showing that the absence of THS is not automatically linked with more compact sounds. However, this could be related to the ability to produce grouped pulses. The pulses are in a single unit or in long trains in C. boraborensis; they can be single, in trains or in groups of two to three in C. homei; they are single or in groups of five to six in E. gracilis. Lagardère et al. (2005) did not separate grouped pulses and pulses in train in their analyses dealing with $C$. homei. We have re-examined their data. The pulse length does not differ $(P=0.93, t$-test $)$ whether the pulses are grouped or in trains. However, the period and interpulse length are, respectively, 1.8 times and 3.3 times shorter $(P<0.001)$ when the pulses are grouped in pairs or in threes. Having these shorter interval times seem possible because the sound-producing system of $C$. homei and E. gracilis is deprived of THS; the mechanism is not restricted by the time the muscle needs to lock onto the swimbladder again. The pulse intervals are likely to be important for recognition (Myrberg, Mohler \& Catala, 1986; Bass \& McKibben, 2003). In some carapid species such as $C$. homei and E. gracilis, the ability to compact pulses could be a way of aiming towards the elaboration of different and/or new kinds of message.

The swimbladder in $C$. homei and $C$. boraborensis is deprived of a long 'neck', as is the case in E. gracilis (Fig. 2). In all Carapini, the snapping back of the anterior part of the swimbladder creates a pressure wave moving in the swimbladder from the front to the back. The vibration here is due to the 'springiness' of the air. The Helmholtz resonator is a narrow-bandwidth device, designed to target specific frequency. It is an acoustic system consisting of an oscillating air plug connected to an air volume. In E. gracilis, the swimbladder could be compared with a bottle with a chamber and a neck. The forepart of the swimbladder, in front of the neck (Fig. 3) can be considered as the external air volume. This parallelism between the swimbladder shape and the Helmholtz resonator could explain why the resulting sound in E. gracilis is naturally more filtered than in C. homei and C. boraborensis (Fig. 9).

The parasitic Encheliophis species are thought to have evolved from species with a commensal way of life (Markle \& Olney, 1990; Parmentier et al., 2000). The THS found in C. boraborensis, C. acus and C. mourlani constitutes a highly complicated biological structure for which we do not know 

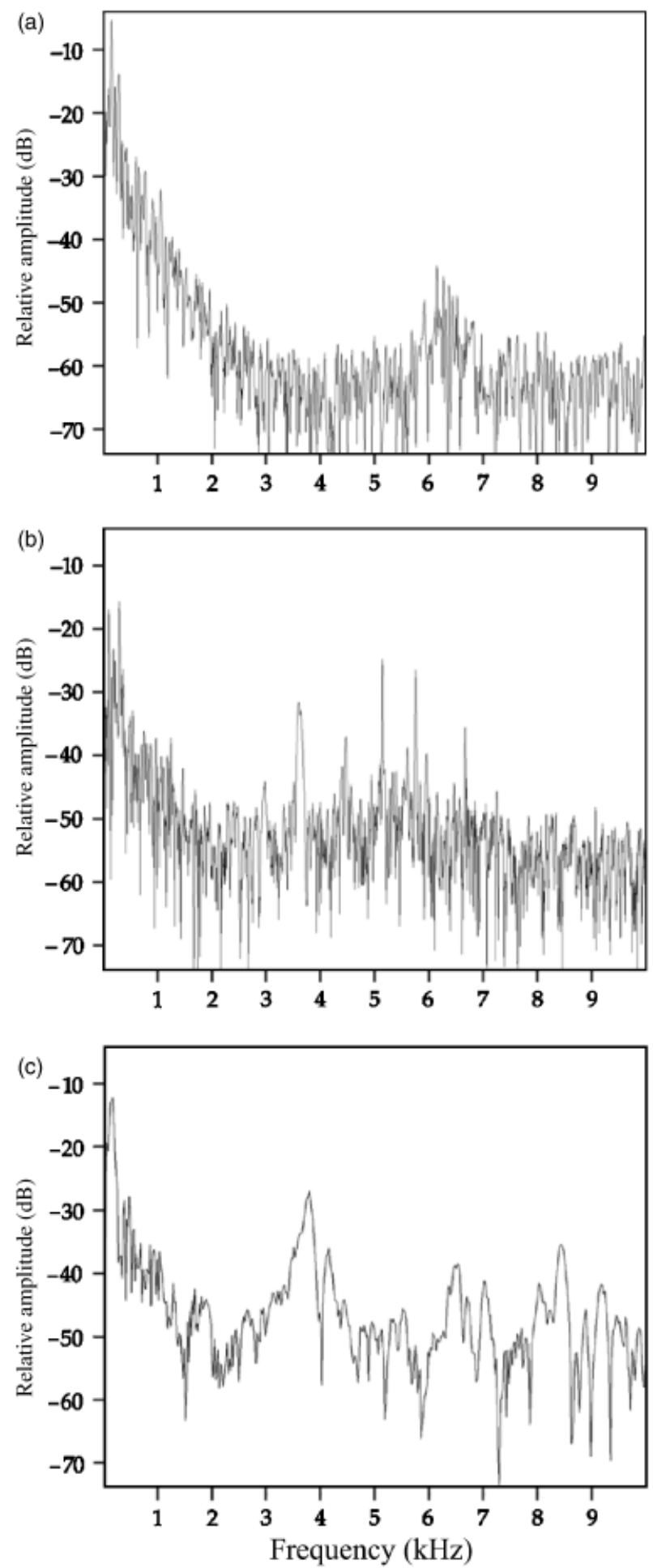

Figure 9 Spectrograms of an isolated pulse in Carapus boraborensis (a), Carapus homei (b) and Encheliophis gracilis (c). The pulses of C. boraborensis and C. homei are from the study of Lagardère et al. (2005). Spectral analysis information: sampling frequency $5500 \mathrm{~Hz}$; Windows: Flat Top; bandwith: $81 \mathrm{~Hz}$. of an equivalent morpho-functional system. Consequently, it is difficult to believe that it represents the primitive condition. The absence of THS in C. homei and E. gracilis would thus correspond to a reversal character. This assumption is reinforced by the insertion of the PSM directly on the swimbladder in the sister group Echiodon (pers. obs.). However, the absence of THS also seems to allow the fish to produce a greater variety of sounds, and it is difficult to believe that the fishes have lost this ability. Further studies are needed to understand the advantage provided by the THS. The case of $C$. homei should be investigated in greater depth because of its dual position. This species is deprived of THS but the shape of its swimbladder is closer to the commensal species. Several studies supported the hypothesis that the environmental conditions play a role in sound divergence between closely related species (e.g. Slabbekoorn \& Smith, 2002). However, all three Carapini species live in the same habitat. Variations in sounds can be considered prezygotic isolating mechanisms leading to speciation (Crocroft \& Ryan, 1995). The morpho-functional aspect of the THS is very particular and it is difficult to imagine intermediate states: the muscle is directly inserted on the swimbladder or it is not the case. Its presence or absence appears automatically related to sound variation as it is the case between $C$. boraborensis and C. homei, which conserves, however, the same kind of swimbladder shape and other morphological structures linked to their way of life (Parmentier et al., 2000). The evolution from commensal to parasitic way of life is more complicated from the communication point of view. The difference between the swimbladder shape of both Carapus and E. gracilis can easily find a great number of intermediate states, and the gradual modification can hardly be a barrier because the frequency spectrum is less subject to carry information (Myrberg et al., 1978).

According to McCauley \& Cato (2000), the fishes have precise control over the muscle contraction rate, whereas they have less control over the swimbladder resonant frequency (this is a function of the depth, the swimbladder volume, the swimbladder wall characteristics and the applied damping). So, it is possible that, for some fishes, the muscle contraction rate conveys more information than the swimbladder resonant frequency. In teleosts, swimbladder sounds have a fundamental frequency ranging from 75 to $300 \mathrm{~Hz}$, which usually corresponds to the muscular contraction rate, placing sonic muscles among the fastest in vertebrates (Rome et al., 1996; Loesser, Rafi \& Fine, 1997; Connaughton et al., 2000; Fine et al., 2001). The speed of the fast-twitch swimbladder muscles could be due in part to their extremely fast relaxation rate (Rome \& Lindstedt, 1998). However, the system is quite different in Carapus in which the sonic muscle tetanizes at $8 \mathrm{~Hz}$ (Parmentier et al., $2006 a$ ). In this fish, the muscular contraction rate does not correspond to the sound frequency but seems to be related to the pulse period (Parmentier et al., 2006a,b). In E. gracilis, the pulse period of $39.89 \mathrm{~ms}$ on an average indicates that the muscle contraction rate is around $25 \mathrm{~Hz}$, three to four times faster than in C. boraborensis. We did not 
find muscular morphological characters in relation to this difference. However, this higher rate could also be due to alternate muscle contraction (Connaughton, 2004).

The secondary sound-producing muscle (SSM) does not present the adaptations found in the primary sound production muscle (PSM). Fibres and myofibrils of the SSM appear to be morphologically similar to white epaxial fibres. The orientation of the epaxial musculature fibres and of their myofibrils is parallel and in a straight line, the $\mathrm{T}$ system/SR surrounds the sarcomere at the Z-line level, and mitochondria are isolated between the myofibrils. As a result, the SSM is highly similar to epaxial muscles. The contraction of the SSM causes a forward and outward displacement of the posterior tips of the epineural ribs, stretching the swimbladder transversally (Parmentier et al., 2003). Depending on the time of contraction, this movement could have different rules. The SSM contraction occurring before the PSM stretches the swimbladder and makes it more rigid, modulating the sound frequency and pulse length. The SSM contraction occurring after PSM contraction could facilitate the snapping back of the anterior part of the swimbladder, modulating the period or the interpulse length.

\section{Acknowledgements}

N. Decloux kindly helped in the microscopic study. E.P. is a research associate of the Fonds National de la Recherche Scientifique of Belgium (FRS-FNRS). This work was supported by the FRFC grant no. 2.4.583.05 from the FRS-FNRS.

\section{References}

Akamatsu, T., Okumura, T., Novarini, N. \& Yan, H.Y. (2002). Empirical refinements applicable to the recording of fish sounds in small thanks. J. Acoust. Soc. Am. 112, 3073-3082.

Arnold, D.C. (1956). A systematic revision of the fishes of the teleost family Carapidae (Percomorphi, Blennioidea), with description of two new species. Bull. Br. Mus. Nat. Hist. 4, 247-307.

Bass, A.H. \& McKibben, J.R. (2003). Neural mechanisms and behaviors for communication in teleost fish. Prog. Neurobiol. 69, 1-26.

Colleye, O., Brié, C., Malpot, E., Vandewalle, P. \& Parmentier, E. (2007). Temporal variability of settlement in Carapidae larvae at Rangiroa atoll. Environ. Biol. Fishes 81, 277-285.

Connaughton, M.A. (2004). Sound generation in the searobin (Prionotus carolinus), a fish with alternate sonic muscle contraction. J. Exp. Biol. 207, 1643-1654.

Connaughton, M.A., Taylor, M.H. \& Fine, M.L. (2000). Effects of fish size and temperature on weakfish disturbance calls: implications for the mechanism of sound generation. J. Exp. Biol. 203, 1503-1512.
Courtenay, W.R. \& McKittrick, F.A. (1970). Sound-producing mechanisms in carapid fishes, with notes on phylogenetic implications. Mar. Biol. 7, 131-137.

Crocroft, R.B. \& Ryan, M.J. (1995). Patterns of advertisement call evolution in toads and chorus frogs. Animal behaviour 49, 283-303.

Emery, D.C. (1880). Fierasfer. Studî interno alla sistematica, l'anatomia e la biologia delle specie mediterranee di questo genere. Atti Accad. Naz. Lic. Memorie 7, 167-254.

Fine, M.L., Malloy, K.L., King, C.M., Mitchell, S.L. \& Cameron, T.M. (2001). Movement and sound generation by the toadfish swimbladder. J. Comp. Physiol. A 187, 371-379.

Hawkins, A.D. (1993). Underwater sound and fish behaviour. In Behaviour of teleost fishes: 129-169. Pitcher, T.J. (Ed.). London: Chapman and Hall.

Hawkins, A.D. \& Myrberg, A.A. (1983). Hearing and sound communication underwater. In Bioacoustics, a comparative approach: 347-405. Lewis, B. (Ed.). London: Academic Press.

Ladich, F., Brittinger, W. \& Kratochvil, H. (1992). Significance of agonistic vocalization in the croaking gourami (Trichopsis vittatus, Teleostei). Ethology 90, 307-314.

Lagardère, J.P., Millot, S. \& Parmentier, E. (2005). Carapus boraborensis and Carapus homei (Carapidae). J. Exp. Zool. 303A, 1066-1074.

Leis, J.M. (1991). The pelagic stages of reef fishes: the larval biology of coral reef fishes. In The ecology of fishes on coral reefs: 183-227. Sale, P.F. (Ed.). San Diego: Academic Press.

Leis, J.M. (2002). Pacific coral-reef fishes: the implications of behaviour and ecology of larvae for biodiversity and conservation, and a reassessment of the open population paradigm. Environ. Biol. Fishes 65, 199-208.

Lobel, P.S. \& Mann, D.A. (1995). Spawning sounds of the damselfish, Dascyllus albisella (Pomacentridae) and relationship to male size. Bioacoustics 6, 187-198.

Loesser, K.E., Rafi, J. \& Fine, M.L. (1997). Embryonic, juvenile and adult development of the toadfish sonic muscle. Anat. Rec. 249, 469-477.

Mann, D.A. \& Lobel, P.S. (1998). Acoustic behavior of the damselfish Dascyllus albisella: behavioral and geographic variation Env. Biol. Fishes 51, 421-428.

Markle, D.F. \& Olney, J.E. (1990). Systematics of the pearlfish (Pisces: Carapidae). Bull. Mar. Sci. 47, 269-410.

McCauley, R.D. \& Cato, D.H. (2000). Patterns of fish calling in a nearshore environment in the Great Barrier Reef. Philos. Trans. Roy. Soc. Lond. B 355, 1289-1293.

Munro, J.L. \& Williams, D.M. (1985). Assessment and management of coral reef fisheries: biological, environmental, and socio-economic aspects. Proc. Fifth Int. Coral Reef Cong. Tahiti 4, 544-578.

Myrberg, A.A., Mohler, M. \& Catala, J. (1986). Sound production by males of a coral reef fish (Pomacentrus 
partitus): its significance to females. Anim. Behav. 34, 913-923.

Myrberg, A.A., Spanier, E. \& Ha, S.J. (1978). Temporal patterning in acoustic communication. In Contrasts in behaviour: 137-179. Reese, E.S. \& Lighter, F.J. (Eds). New York: John Wiley and Sons.

Parmentier, E., Castillo, G., Chardon, M. \& Vandewalle, P. (2000). Phylogenetic analysis of the pearlfish tribe Carapini (Pisces: Carapidae). Acta Zool. (Stockholm) 81, 293-306.

Parmentier, E. \& Das, K. (2004). Commensal vs. parasitic relationship between Carapini fish and their hosts: some further insight through $\mathrm{d} 13 \mathrm{C}$ and $\mathrm{d} 15 \mathrm{~N}$ measurements. J. Exp. Mar. Biol. Ecol. 301, 47-58.

Parmentier, E., Fine, M., Vandewalle, P., Ducamp, J.J. \& Lagardère, J.P. (2006b). Sound production in two carapids (Carapus acus and C. mourlani) and through the sea cucumber tegument. Acta Zool. 87, 113-119.

Parmentier, E., Lagardère, F. \& Vandewalle, P. (2002). Relationships between inner ear and sagitta growth during ontogenesis of three Carapini species and consequences of life-history events on the otolith microstructure. Mar. Biol. 141, 491-501.

Parmentier, E., Lagardère, J.P., Braquenier, J.B., Vandewalle, P. \& Fine, M.L. (2006a). Sound production mechanism in carapid fish: first example with a slow sonic muscle. J. Exp. Biol. 209, 2952-2960.

Parmentier, E. \& Vandewalle, P. (2003). Morphological adaptations of Pearlfish (Carapidae) to their various habitats. In Fish adaptations: 261-276. Val, A.L. \& Kapoor, B.G. (Eds). India: Oxford \& IBH.

Parmentier, E. \& Vandewalle, P. (2005). Further insight on carapid-holothuroid relationships. Mar. Biol. 146, 455-465.

Parmentier, E., Vandewalle, P. \& Lagardère, J.P. (2003). Sound producing mechanisms and recordings in three Carapidae species. J. Comp. Physiol. A 189, 283-292.

Rome, L.C. \& Lindstedt, S. (1998). The quest for speed: muscles built for high-frequency contractions. News Physiol. Sci. 13, 261-268.

Rome, L.C., Syme, D.A., Hollingworth, S., Lindstedt, S.L. \& Baylor, S.M. (1996). The whistle and the rattle: the design of sound producing muscles. Proc. Natl. Acad. Sci.93, 8095-8100.

Shen, S.C. \& Yeh, H.S. (1987). Study on pearlfishes (Ophidiiformes: Carapidae) of Taïwan. J. Taïwan Mus. 40, 45-56.

Smith, T.B. (2002). Bird song, ecology and speciation. Philos. Trans. Roy. Soc. Lond. 357, 493-503.

Smith, C.L. (1964). Some Pearlfishes from Guam, with notes on their ecology. Pac. Sci. 18, 34-40.

Trott, L.B. (1970). Contribution of the biology of Carapid fishes (Paracanthopterygian: Gadiformes). Univ. Calif. Publ. Zool. 89, 1-41.

Winn, H.E. (1964). The biological significance of fish sounds. In Marine bio-acoustics: 213-231. Tavolga, W.N. (Ed.). Oxford: Pergamon Press. 